\title{
A Study on the Evaluation of Heating and Cooling Energy Efficiency in Residential Buildings for Climatic Zones of Turkey
}

\author{
Suzi Dilara Mangan and Gül Koçlar Oral \\ Faculty of Architecture, Istanbul Technical University, Istanbul 80191, Turkey
}

Received: September 05, 2014 / Accepted: October 13, 2014 / Published: December 31, 2014.

\begin{abstract}
In Turkey, most of the common type projects of mass production residential buildings are being developed and constructed by TOKI (Housing Development Administration of Turkey). These buildings, in which energy efficient approach has been disregarded for years, cause to gradually increase on heating and cooling energy consumptions. In regards to national economics, it is essential to evaluate energy efficiency and to develop suggestions to decrease energy consumptions in residential buildings. To achieve appropriate solutions, cost evaluation also becomes necessary. Therefore, this paper aims to introduce a study which serves the purpose of producing a choice of energy efficient solutions in order to reduce energy consumptions and energy cost. In this study, different heating and cooling energy efficient scenarios have been developed for a selected residential building, constructed by TOKI, for climatic zones of Turkey. For each scenario, energy simulations have been executed by means of the simulation program-DesignBuilder, the user-friendly visual interface of EnergyPlus, and cost analysis has been carried out by using the net present value and discounted payback period method. As a result, energy and cost effective solutions have been presented and discussed for different climatic zones.
\end{abstract}

Key words: Building energy performance, residential buildings, energy efficient retrofitting, energy cost.

\section{Introduction}

Buildings sector is among the most energy intensive sector, and it is looming large in terms of energy consumption and environmental impacts. It shall be considered as a priority area for all policies dealing with increasing energy efficiency and combating environmental problems.

In Turkey, built-up areas, disregarding energy efficient approach for a long time, have been causing the gradually increase on energy consumption. Especially, nationwide investments of mass production residential buildings by TOKI (Housing Development Administration of Turkey) that has been responsible to meeting the dwelling demand rapidly since 2003, have the significant role in energy efficiency level of

Corresponding author: Suzi Dilara Mangan, M.Sc architect, research fields: building physics, energy use in buildings, renewable energy, simulations and modelling. E-mail: dilaramangan@yahoo.com. building sector. In terms of national energy economics, evaluating the energy efficiency level of these existing buildings, developing suggestions for the reduction of energy costs, in other words, energy efficient retrofitting is extremely important at the present days.

Depending on rising standards of living and population growth, the energy demand increases in spite of energy resources depletion. A great portion of energy is consumed by existing residential buildings to achieve comfort conditions in Turkey. On the other hand, it is necessitated to alleviate energy import dependency of Turkey and reduce the environmental effects related to energy consumption, efficient use of energy in buildings. Efficient use of energy means minimizing the energy need without compromising the social welfare, comfort conditions, required performance level and quality. In this context, energy efficient retrofitting of existing residential buildings in 
building sector has great importance to achieve the energy efficiency potential of $35 \%$, declared by the General Directorate of Electrical Power Resources Survey and Development Administration of Turkey [1].

To appraise this potential and increase energy efficiency in Turkey, energy costs have to be taken into account. In parallel with increasing energy demand, energy cost is also rising. Furthermore, while various scenarios are developing to reduce heating and cooling energy from the existing residential buildings, cost effectiveness of these scenarios has also to be proven. Therefore, to solve energy problems, while realizing the increasing energy demand and energy cost, energy and cost effective retrofitting of existing residential buildings has gradually greater importance. This paper aims to introduce a study which has been carried out with an evaluation on energy and thermal performance for residential envelopes by developed scenarios, ensuring cost effective energy efficiency opportunities, also incorporated into new buildings.

In this paper, the potential improvement of scenarios was assessed in terms of energy savings, by using the energy simulation program, as well as the costs of these options, according to net present value and discounted payback period method, for the different climatic zones of Turkey.

\section{Methodology}

In this study, different energy efficient scenarios, based on building envelope, were applied to existing residential building to evaluate heating and cooling energy consumptions, cost of energy consumptions and initial capital investment of these scenarios. The heating and cooling energy consumptions of existing residential building have been calculated for Istanbul, Ankara, Antalya, Diyarbakir and Erzurum which are representative cities of Turkey for temperate humid, temperate dry, hot humid, hot dry and cold climatic zones, respectively. These climatic zones are based on the results of the previous scientific researches which had been carried out in Istanbul Technical University [2]. On the other hand, in Turkish Standard TS 825-"Rules of Heat Insulation in Building", Turkey has divided into four different climatic zones, where Istanbul and Diyarbakir are taken into the same climatic zone, in spite of different climatic characteristics [3]. Table 1 shows the explanation of different climatic zones of Turkey and representative cities of these climatic zones.

\subsection{Building Model}

The selected existing mass housing project was constructed by TOKI in 2008 in Istanbul. This project was designed on $25.312 \mathrm{~m}^{2}$ as seven blocks (A1, A2, A3, B1, B2, C, D), 408 flats (Fig. 1).

For this study, A1 Block (mentioned as ERB (existing residential building)) was taken for energy performance calculation. It is 17-storey high (two basement floor, ground floor, 12 typical floors and the 13th floor as dublex). The block was designed as four apartments per typical floor, two apartments and storages on the basement floors, two dublex apartments on the 13th floor and entrance hall on the ground floor. The building height is $48.28 \mathrm{~m}$, floor to floor height is $2.79 \mathrm{~m}$ and floor area is $573 \mathrm{~m}^{2}$. ERB form factor (width/length) is $1.37 . \mathrm{A} / \mathrm{V}$ (total facade area/building volume) is 0.19 .

ERB and the other blocks were modeled on site according to project, to take into the shading effects of buildings in energy performance calculations.

For ERB, each apartment area and hall were accepted as a zone, means heated/cooled area. The core units (stairs, elevators, and fire stairs) and ventilation plenums were accepted not conditioned areas, as seen in Fig. 2.

Table 1 Characteristics of the climate zones of Turkey.

\begin{tabular}{llll}
\hline Climatic zone [2] & City & $\begin{array}{l}\text { Climatic } \\
\text { zone [3] }\end{array}$ & $\begin{array}{l}\text { Heating-degree } \\
\text { days [4] }\end{array}$ \\
\hline Temperate humid & Istanbul & 2. Zone & 1,886 \\
Temperate dry & Ankara & 3. Zone & 3,307 \\
Hot humid & Antalya & 1. Zone & 972 \\
Hot dry & Diyarbakir & 2. Zone & 2,086 \\
Cold & Erzurum & 4. Zone & 4,785 \\
\hline
\end{tabular}



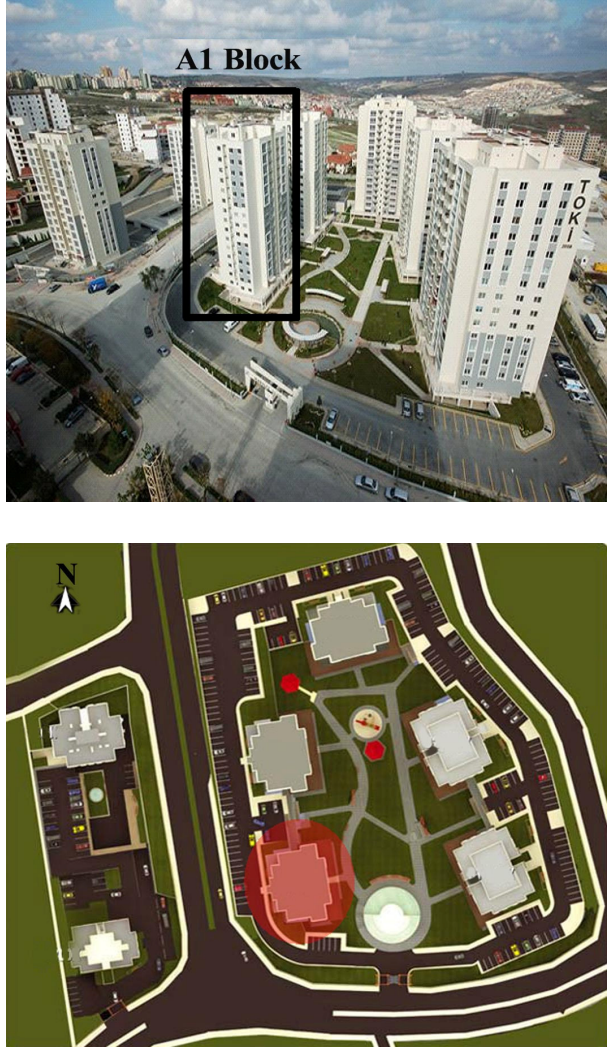

Fig. 1 General view of existing mass housing project and site plan.

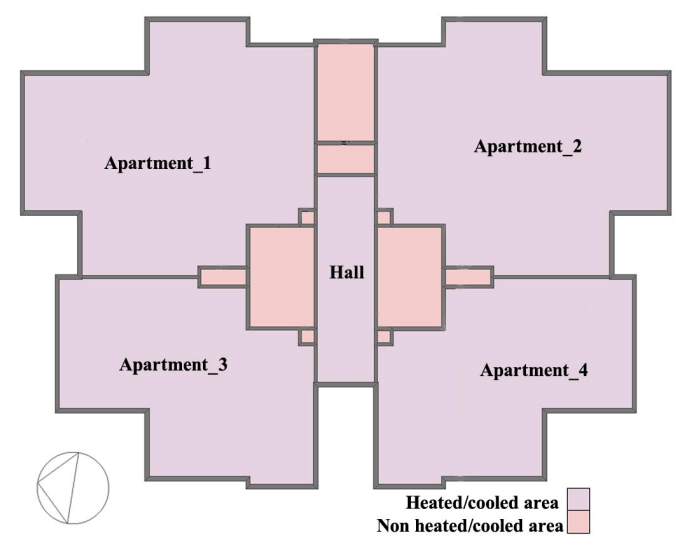

Fig. 2 Schematic plan of ERB.

According to construction characteristics of ERB, for external walls, type 1 and type 2 consisted of $20 \mathrm{~cm}$ aerated concrete block, $20-\mathrm{cm}$ reinforced concrete block, respectively. For flat roofs, the finish layer was distinctive mark for two types. The finish layer for type 1 was ceramic, for type 2 was gravel. Thickness of existing insulation of the wall, ground floor and roof constructions and relevant $U$ values, are given in Table 2.
Table 2 Insulation thickness and of existing opaque components.

\begin{tabular}{lll}
\hline $\begin{array}{l}\text { Opaque } \\
\text { component }\end{array}$ & Insulation & $\begin{array}{l}U \text { value } \\
\left(\mathrm{W} / \mathrm{m}^{2} \cdot \mathrm{K}\right)\end{array}$ \\
\hline $\begin{array}{l}\text { External wall (type 1) } \\
\text { External wall (type 2) }\end{array}$ & XPS-5 $\mathrm{cm}$ & $U_{\text {wall_1 }}=0.371$ \\
Xround floor & XPS-4 cm & $U_{\text {wall_2 }}=0.576$ \\
Flat roof (type 1) & EPS-5 cm & $U_{\text {floor }}=0.513$ \\
Flat roof (type 2) & EPS-5 cm & $U_{\text {roof } 1}=0.547$ \\
\hline roof $2=0.546$ \\
\hline
\end{tabular}

Window type was double glazed (4-mm clear glass + 12-mm air + 4-mm clear glass, $\left.U: 2.725 \mathrm{~W} / \mathrm{m}^{2} \cdot \mathrm{K}\right)$ and PVC (polyvinyl chloride) frame $(60 \mathrm{~mm}, U: 1.912$ $\left.\mathrm{W} / \mathrm{m}^{2} \cdot \mathrm{K}\right)$. The transparency ratios as a percentage of the facades were 14, 24, 15, 30 for the north, east, south and west direction, respectively.

\subsection{Calculation of Heating and Cooling Energy Consumptions for ERB}

In order to evaluate the energy performance of ERB, annual heating and cooling energy consumptions were calculated by using dynamic energy simulation program "DesignBuilder" that is user-friendly visual interface of Energy Plus [4].

To perform energy simulations, outdoor climate data for five climatic zones of Turkey, were taken from "IWEC (International Weather for Energy Calculations)" files. For the energy consumption calculations, "typical meteorological year" file was used. Metabolic rates were set as $110 \mathrm{~W} /$ person for apartment zones. The thermal resistance of the clothing is measured in units of "clo" and for winter clothing 1 clo, for summer clothing 0.5 clo were used.

According to environmental control, for apartment zones, the comfort value for indoor temperature was assumed to be $21{ }^{\circ} \mathrm{C}$ for heating period and $25{ }^{\circ} \mathrm{C}$ for cooling period. For halls, heating set point temperature was accepted $18{ }^{\circ} \mathrm{C}$. Natural ventilation was taken into calculations as minimum fresh air (1/s-person) (litre/second) parameter, accepted value was 10 [5]. Hot water radiator central heating system was defined. $C O P_{\text {heating }}$ was accepted 0.65 . Fuel type was defined as natural gas. Cooling system was not designed for the ERB. For this study, characterized cooling system was accepted to evaluate how much energy would be need 
for cooling of ERB. COP $P_{\text {cooling }}$ was accepted 4.50. Fuel type was defined as electricity. According to the cooling demand data, if the indoor air temperature was higher than $23{ }^{\circ} \mathrm{C}$, and the outdoor air temperature was less than the indoor air temperature, natural ventilation would be accepted "on" mode.

\subsection{Improvement of Scenarios}

In order to decrease energy consumption for heating and cooling, different scenarios related to building envelope, were defined in three categories as below:

- improving the opaque components of building envelope (walls, ground floor, roof) $\left(\mathrm{Sc}_{1}, \mathrm{Sc}_{2}\right)$;

- improving the transparent components of building envelope (windows) $\left(\mathrm{Sc}_{3}, \mathrm{Sc}_{4}\right)$;

- combination of previous scenarios $\left(\mathrm{Sc}_{1}, \mathrm{Sc}_{2}, \mathrm{Sc}_{3}\right.$, $\left.\mathrm{Sc}_{4}\right)$.

Overview and characteristics of scenarios, mentioned above, are shown in Table 3. Energy simulations for each defined scenarios as above, were carried out for the cities, mentioned in Table 1.

The assumptions for the scenarios of improving the opaque elements were based on the upper limit $U$ values for walls, ground floor, and roof, which were defined in TS 825, shown in Table 4.

According to $\mathrm{Sc}_{1}$, existing opaque elements which were not appropriate to the upper limit $U$ values, defined by TS 825 , current insulation thickness were increased to achieve them. As to $\mathrm{Sc}_{2}$ (the second scenario), extensive green roof application (infill soil thickness is $15 \mathrm{~cm}$ ) was used. For different climatic zones, if the calculated $U$ value of green roof was not appropriate to $U_{\text {roof }}$ value, defined by TS 825 , existing insulation thickness would be increased. For $\mathrm{Sc}_{3}$ (the third scenario), glass type was varied according to the conditions of climatic zones. For Istanbul, Ankara, Diyarbakir, heat conservation glasses (low-e coated on second pane), for Erzurum, heat conservation glasses (low-e coated on third pane), for Antalya, solar control and heat conservation glasses (reflective and low-e coated on second pane) were used, instead of clear
Table 3 Characteristics of scenarios for ERB.

\begin{tabular}{ll}
\hline Scenario & Assumptions \\
\hline $\mathrm{Sc}_{1}$ & Adding insulation layer according to TS 825 \\
$\mathrm{Sc}_{2}$ & $\begin{array}{l}\text { Application of green roof on the existing flat roof } \\
\text { areas }\end{array}$ \\
$\mathrm{Sc}_{3}$ & Changing the existing window type \\
$\mathrm{Sc}_{4}$ & $\begin{array}{l}\text { Adding solar control devices on south, west and } \\
\text { east facades }\end{array}$ \\
$\mathrm{Sc}_{5}$ & Applying all the previous scenarios together \\
\hline
\end{tabular}

Table 4 The upper limit $U$ values according to TS 825 .

\begin{tabular}{llll}
\hline Representative city & $\begin{array}{l}U_{\text {wall }} \\
\left(\mathrm{W} / \mathrm{m}^{2} \cdot \mathrm{K}\right)\end{array}$ & $\begin{array}{l}U_{\text {floor }} \\
\left(\mathrm{W} / \mathrm{m}^{2} \cdot \mathrm{K}\right)\end{array}$ & $\begin{array}{l}U_{\text {roof }} \\
\left(\mathrm{W} / \mathrm{m}^{2} \cdot \mathrm{K}\right)\end{array}$ \\
\hline Istanbul-Diyarbakir & 0.60 & 0.60 & 0.40 \\
Ankara & 0.50 & 0.45 & 0.30 \\
Antalya & 0.70 & 0.70 & 0.45 \\
Erzurum & 0.40 & 0.40 & 0.25 \\
\hline
\end{tabular}

double glazed base type. By $\mathrm{Sc}_{4}$ (the forth scenario), aluminum window blinds were used as solar control devices. Solar control devices were located on the west, south and east facades of ERB. Operation schedule of solar control devices were defined as "overheated period of different climatic zones of Turkey" [6], based on the results of the previous scientific researches which had been carried out in Istanbul Technical University. $\mathrm{Sc}_{5}$ (final scenario) was a combination of the previous scenarios.

Heating, cooling and total energy consumptions (based on primary energy and primary energy factors for electricity and natural gas were taken from CEN (European Committee for Standardization) Standard EN 15603 [7] for all scenarios were compared with the ERB current consumptions, according to each climatic zones and calculation results are shown in Figs. 3-5.

\subsection{Cost Analysis}

To understand the economic feasibility of energy efficiency scenarios, cost analysis was performed according to NPV (net present value) and DPP (discounted payback period) method.

In this study, square meter unit prices of energy efficient components were obtained from related companies in Turkey. The unit price of electricity and natural gas were taken from Turkish Electricity Transmission Company [8], and Istanbul Gas 
Distribution Inc. [9], respectively. For this study, a fixed annual percentage interest rate of $10.41 \%$ [10] and inflation rate of $8.65 \%$ [11] were used. Evaluation period of cost analysis was accepted as 20 years.

Initial capital investment was comprised of insulation (walls, ground floor, roof) and window cost, assumed to be the same for each city. For each scenario, NPV was calculated according to the sum of initial capital investment and discounted total energy costs for 20 years. Table 5 shows the incremental cost of each scenarios, compared to the base case, the corresponding annual energy savings (\$), NPV (\$) and DPP (year-month).

\subsection{Results}

The evaluation results of heating and cooling energy consumptions of ERB according to different climatic zones, using by DesignBuilder simulation program, can be summarized as below.

As seen in Fig. 3, compared to the base case lower heating energy consumption was achieved by $\mathrm{Sc}_{1}, \mathrm{Sc}_{2}$, $\mathrm{Sc}_{3}$ and $\mathrm{Sc}_{5}$. On the other hand, using solar control devices on the west, south and west facades only for overheated period of different climatic zones $\left(\mathrm{Sc}_{4}\right)$, did not have any effect on heating energy consumptions. $\mathrm{Sc}_{1}$, adding insulation layer, provided the lowest heating energy consumption for Ankara and Erzurum, compared to other cities. As to $\mathrm{Sc}_{1}$, energy consumptions for heating were decreased by $8 \%$ for Ankara, 13\% for Erzurum, compared to the base case. For Istanbul, Antalya and Diyarbakir, by applying $\mathrm{Sc}_{2}$, green roof application, heating energy consumptions were reduced by $4 \%, 9 \%, 6 \%$, respectively. According to $\mathrm{Sc}_{5}$, combination of all scenarios, the heating energy consumptions for Antalya increased more than the base case while decreasing the other cities' heating energy consumptions. By applying $\mathrm{Sc}_{5}$, the reduction ratios of heating energy consumptions, except Antalya, were more than that of $\mathrm{Sc}_{1}$ and $\mathrm{Sc}_{2}$.

As shown in Fig. $4, \mathrm{Sc}_{3}, \mathrm{Sc}_{4}$ and $\mathrm{Sc}_{5}$ reduced the cooling energy consumptions compared to the base

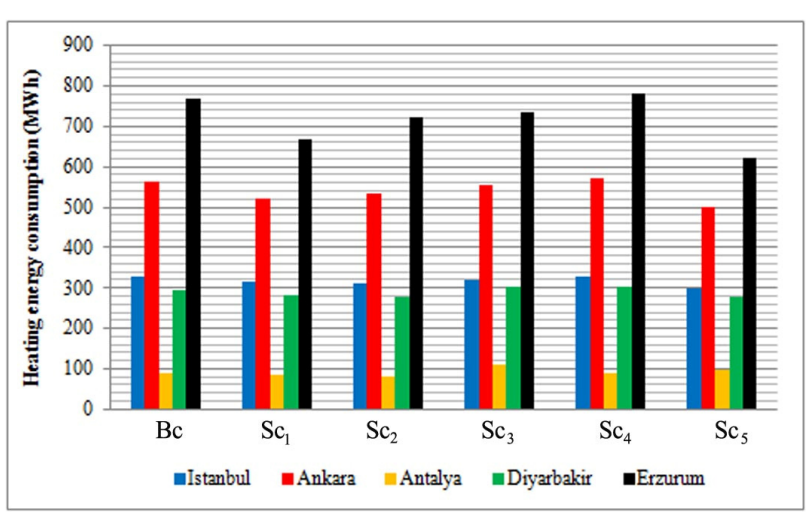

Fig. 3 Heating energy consumptions of scenarios.

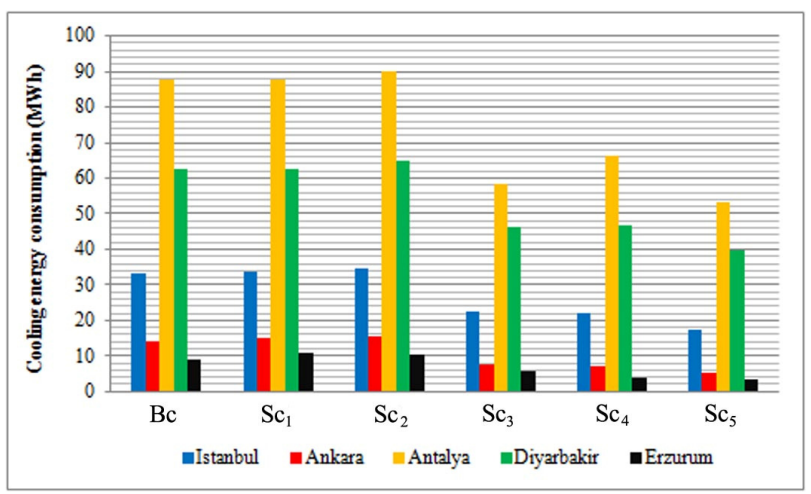

Fig. 4 Cooling energy consumptions of scenarios.

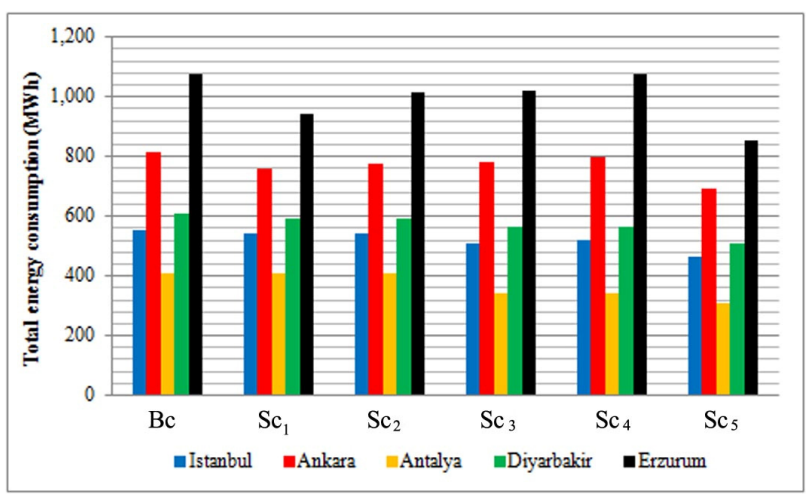

Fig. 5 Total (primary energy) energy consumptions of scenarios.

case. $\mathrm{Sc}_{1}$, adding insulation layer, and $\mathrm{Sc}_{2}$, green roof application, did not have any effect on decreasing the cooling energy consumptions. By applying $\mathrm{Sc}_{3}$, and $\mathrm{Sc}_{4}$, the reduction ratios of cooling energy consumptions were $32 \%, 34 \%$ for Istanbul, $46 \%, 52 \%$ for Ankara, 33\%, 25\% for Antalya, 26\%, 26\% for Diyarbakir, 37\%, 57\% for Erzurum, respectively. By applying $\mathrm{Sc}_{5}$, cooling energy consumptions were also reduced more than that of $\mathrm{Sc}_{3}$ and $\mathrm{Sc}_{4}$. 
As seen in Fig. 5, all scenarios provided lower total energy consumptions, based on primary energy, than the base case for all representative cities of climatic zones. But one of these scenarios provided the lowest total primary energy consumptions than the others, compared to the base case. For Istanbul and Diyarbakir, by applying $\mathrm{Sc}_{3}$, total primary energy consumptions were reduced by $8 \%, 7 \%$, respectively. For Ankara and Erzurum, by applying $\mathrm{Sc}_{1}$, total primary energy consumptions were reduced by $7 \%$ and $12 \%$, respectively. For Antalya, by applying $\mathrm{Sc}_{4}$, total primary energy consumptions were reduced by $17 \%$. As to $\mathrm{Sc}_{5}$, the reduction ratios of total primary energy consumptions, for Istanbul, Ankara, Antalya, Diyarbakir and Erzurum were 16\%, 15\%, 24\%, 16\%, $20 \%$, respectively.

The evaluated energy consumption values of each scenario were used to calculate the annual cost savings. To determine the NPV value for each scenario, the sum of energy cost (electricity + natural gas) and initial capital investment of each scenario were used to calculate the present worth of cumulative cost for the life span of 20 years. DPP was also determined to analyze payback periods of scenarios as year. Table 5 shows the cost calculations, performed according to financial data of Turkey. According to the results, among the scenarios, $\mathrm{Sc}_{1}$ and $\mathrm{Sc}_{3}$ could be accepted as cost efficient scenario, in terms of higher NPV values and short payback periods compared to the other scenarios. $\mathrm{Sc}_{3}$ was the most efficient scenario than $\mathrm{Sc}_{1}$ in hot climatic zones. In terms of negative NPV values, compared to the base case and long payback periods more than 20 years, $\mathrm{Sc}_{2}$ and $\mathrm{Sc}_{4}$ were not economically advantageous for all cities, especially because of incremental cost of these scenarios. In hot climatic zones, despite annual savings for $\mathrm{Sc}_{4}$ was higher than that of $\mathrm{Sc}_{1}$ and $\mathrm{Sc}_{3}$, applying this scenario could be avoided because of high additional cost. Also for $\mathrm{Sc}_{5}$, the same reasons, mentioned for $\mathrm{Sc}_{4}$ and $\mathrm{Sc}_{2}$, made negative impact on the applicability of this scenario. On the other hand, when energy costs are expected to increase faster than building costs, the cost-effectiveness of the scenarios will be even higher.

Table 5 Cost benefits of scenarios.

\begin{tabular}{|c|c|c|c|c|c|c|}
\hline $\begin{array}{l}\text { Sc. } \\
\text { No. }\end{array}$ & Assumptions & City & $\begin{array}{l}\text { Additional cost } \\
(\$)\end{array}$ & $\begin{array}{l}\text { Total annual savings } \\
\text { (\$) }\end{array}$ & $\begin{array}{l}\text { NPV } \\
(\$)\end{array}$ & $\begin{array}{l}\text { DPP } \\
\text { (y) }\end{array}$ \\
\hline \multirow{5}{*}{$\mathrm{Sc}_{1}$} & \multirow{5}{*}{$\begin{array}{l}\text { Adding insulation layer } \\
\text { according to TS } 825\end{array}$} & Istanbul & 1,383 & 453 & 6,204 & $3 \mathrm{y}$ \\
\hline & & Ankara & 8,173 & 1,874 & 23,199 & $5 y$ \\
\hline & & Antalya & 922 & 163 & 1,798 & $6 y$ \\
\hline & & Diyarbakir & 1,383 & 485 & 6,729 & $3 y$ \\
\hline & & Erzurum & 18,728 & 4,450 & 55,751 & $5 y$ \\
\hline \multirow{5}{*}{$\mathrm{Sc}_{2}$} & \multirow{5}{*}{$\begin{array}{l}\text { Application of green roof on the } \\
\text { existing flat roof areas }\end{array}$} & Istanbul & 24,499 & 440 & $-17,136$ & - \\
\hline & & Ankara & 25,881 & 1,297 & $-4,172$ & - \\
\hline & & Antalya & 24,499 & 23 & $-24,121$ & - \\
\hline & & Diyarbakir & 24,499 & 450 & $-16,961$ & - \\
\hline & & Erzurum & 26,803 & 1,992 & 6,541 & $15 \mathrm{y}$ \\
\hline \multirow{5}{*}{$\mathrm{Sc}_{3}$} & \multirow{5}{*}{$\begin{array}{l}\text { Changing the existing window } \\
\text { type }\end{array}$} & Istanbul & 6,818 & 2,001 & 26,677 & $4 \mathrm{y}$ \\
\hline & & Ankara & 6,818 & 1,379 & 16,270 & $5 y$ \\
\hline & & Antalya & 9,221 & 3,599 & 51,009 & $3 y$ \\
\hline & & Diyarbakir & 6,818 & 2,245 & 30,750 & $3 y$ \\
\hline & & Erzurum & 6,818 & 2,071 & 27,846 & $4 y$ \\
\hline \multirow{5}{*}{$\mathrm{Sc}_{4}$} & \multirow{5}{*}{$\begin{array}{l}\text { Adding solar control devices on } \\
\text { south, west and east facades }\end{array}$} & Istanbul & 56,746 & 1,766 & $-27,197$ & - \\
\hline & & Ankara & 56,746 & 843 & $-42,641$ & - \\
\hline & & Antalya & 56,746 & 3,356 & -575 & $20 \mathrm{y}$ \\
\hline & & Diyarbakir & 56,746 & 2,217 & $-19,641$ & - \\
\hline & & Erzurum & 56,746 & 177 & $-53,788$ & - \\
\hline \multirow{5}{*}{$\mathrm{Sc}_{5}$} & \multirow{5}{*}{$\begin{array}{l}\text { Applying all the previous } \\
\text { scenarios together }\end{array}$} & Istanbul & 89,446 & 3,741 & $-26,834$ & - \\
\hline & & Ankara & 97,618 & 4,459 & $-22,987$ & - \\
\hline & & Antalya & 91,388 & 4,955 & $-8,451$ & - \\
\hline & & Diyarbakir & 89,446 & 4,399 & $-15,829$ & - \\
\hline & & Erzurum & 109,095 & 7,739 & 20,424 & $16 \mathrm{y}$ \\
\hline
\end{tabular}




\section{A Study on the Evaluation of Heating and Cooling Energy Efficiency in Residential Buildings for Climatic Zones of Turkey}

\section{Conclusions}

In Turkey, TOKI (Housing Development Administration of Turkey) undertakes a significant role for nationwide investments in the building sector, and especially, in residential buildings. TOKI embarked on a construction programme that delivered 500,000 units built to earthquake resistant standards between 2006 and 2011. However, in a development process which echoed the earlier experience of many European countries, the emphasis was on volume and speed of production rather than on quality standards. Much of the production was in the form of peripheral estates of high rise blocks, with a low priority for environmental standards [12]. Contrarily, by UNDP (the United Nations Development Programme) project promoting energy efficiency in buildings in Turkey, TOKI, one of the partners of this project, will have a significant effect on reforming the residential building industry based on identified energy efficiency investments [13].

Within this context, it is a key area of focus for energy conservation in Turkey to reduce energy consumption related to heating and cooling in existing buildings by improving the building envelope as energy and cost effective, because the energy consumption of existing residential buildings drains a major part of Turkey's energy resources, so is in other developing countries. It is obvious that the reduction of energy costs in residential buildings will also contribute to cost reduction in other sectors. Therefore, in this study, possible scenarios were advised to improve the energy efficiency of an existing building, built by TOKI, according to different climatic zones, and economic feasibility of these scenarios was analyzed. According to the results of the analyses, a reduction of $4 \%-13 \%$ in annual heating energy consumption, a reduction of $25 \%-57 \%$ in annual cooling energy consumption, and a reduction of $7 \%-20 \%$ in annual total energy consumption based on primary energy were found, and positive NPVs were achieved for all climatic zones by $\mathrm{Sc}_{1}$ (adding insulation layer) and $\mathrm{Sc}_{3}$ (changing existing window type) and DPP varied between approximately two and 15 years for these scenarios.

In this study, limited cost-optimal energy efficient scenarios related to building envelope were analyzed to reach general results and provide energy and cost efficient scenarios according to different climatic zones of Turkey. According to the results of this study, it has a great importance for the reduction of energy costs to implement energy efficiency program for existing residential buildings at modest cost, concentrating on space heating and cooling energy consumptions, regarding to climatic zones. Increasing awareness to the impact of rising energy prices on heating and cooling energy consumptions costs will provide insight into the energy regulations as how to exploit opportunities to minimize the heating and cooling energy consumptions, in accordance with the regional and climatic conditions. For that, this analysis becomes more crucial to make sense of different energy efficient scenarios as economically feasible for retrofitting mass production buildings in Turkey, and to create a design guide related to climatic zones.

\section{Acknowledgements}

This study was derived from the Ph.D. thesis of Suzi Dilara Mangan and has been supported by a grant from the Scientific Research Centre of Istanbul Technical University (Project No.: 36983). This study was also presented in the 11th REHVA World Congress \& 8th International Conference on IAQVEC, CLIMA 2013, Prague, Czech Republic.

\section{References}

[1] Ministry of Environment and Urbanization. 2011. Republic of Turkey National Climate Change Action Plan 2011-2023.

[2] Zeren, L. 1987. "A Study on Regulation Model Related to New Settlements and Buildings in Turkey." Urban and Environmental Research Center, Istanbul Technical University, Istanbul.

[3] Turkish Standards. 2008. "Rules of Heat Insulation in Building." TS 825. 


\section{Residential Buildings for Climatic Zones of Turkey}

[4] DesignBuilder Software. 2011. "User manual of Design Builder 3.0.0.105." Accessed December 2, 2011. http://www.designbuilder.co.uk./.

[5] Cilingiroglu, S. 2010. "Indoor Air Quality." Tesisat Mühendisliği 115 (February): 23-42.

[6] Berköz, E., Küçükdoğu, M., Yilmaz, Z., Kocaaslan, G., Yıldız, E., Köknel, A., Unver, R., Ak, F., Enarun, D., and Yildı, D. 1995. Energy Efficient Building and Settlement Design. Research report (No: 201), the Scientific and Technical Research Council of Turkey, Istanbul.

[7] Molenbroek, E., Stricker, E., and Boermans, T. 2011. Primary Energy Factors for Electricity in Buildings. An energy report, Ecofys Netherlands BV.

[8] EDAS. 2012. "Electricity Tariff." Turkish Electricity Distribution Company. Accessed October 22, 2012. http://www.tedas.gov.tr/BilgiBankasi/Sayfalar/ElektrikTa rifeleri.aspx.

[9] IGDAS. 2012. "Natural Gas Tariff." Istanbul Gas Distribution Inc.. Accessed October 20, 2012. http://www.igdas.com.tr/SatisTarifesi?id=140\&lang=tr\&s $\mathrm{c}=0$.

[10] TCBM. 2012. “Central Bank Interest Rate." Turkey's Central Bank, Banking and Financial Institutions Department. Accessed October 28, 2012. http://www.tcmb.gov.tr/wps/wcm/connect/TCMB+TR/T $\mathrm{CMB}+\mathrm{TR} /$ Main+Menu/Para+Politikasi/Merkez+Bankasi + Faiz+Oranlari.

[11] TSI. 2012. "Producer Price Index." Turkish Statistical Institute. Accessed November 12, 2012. http://www.tuik.gov.tr/PreTabloArama.do?metod=search \&araType $=\mathrm{vt}$.

[12] Kocabas, A. 2013. "The Transition to Low Carbon Urbanization in Turkey: Emerging Policies and Initial Action." Habitat International 37: 80-87.

[13] UNDP. 2011. "Promoting Energy Efficiency in Buildings in Turkey." The United Nations Development Programme). Accessed December 3, 2012. http://www.tr.undp.org/content/turkey/en/home/operations/ projects/poverty_reduction/promoting_energy_efficiency_i n_buildings_in_turkey/. 